\title{
ШЛЯХИ, ХАРАКТЕР ТА ТИПИ ЗАПОЗИЧЕНЬ 3 УКРАЇНСЬКОЇ МОВИ В МОВУ РОСІЙСЬКУ (на матеріалі словника живої російської мови В. Даля)
}

\author{
ТЕТЯНА КОСМЕДА \\ Університет імені Адама Міцкевича, Познань - Польща \\ tkosmeda@gmail.com; ORCID: 0000-0001-8912-2888 \\ ГАЛИНА НАМАЧИНСЬКА \\ Дрогобицький державний педагогічний університет імені Івана Франка, \\ Дрогобич - Україна \\ fokysnam@ukr.net; ORCID: 0000-0002-2984-8422 \\ DROGI DOSTANIA SIĘ DO JEZZYKA, CHARAKTER \\ ORAZ TYPY ZAPOŻYCZEŃ Z JĘZYKA UKRAIŃSKIEGO NA ROSYJSKI \\ (na materiale słownika żywego języka rosyjskiego W. Dala) \\ TETIANA KOSMEDA \\ Uniwersytet imenia Adama Mickiewicza, Poznań — Polska \\ HAEYNA NAMACZYNSKA \\ Państwowy Uniwersytet Pedagogiczny imienia Iwana Franki, \\ Drohobycz — Ukraina
}

STRESZCZENIE. W artykule wyznaczono na podstawie analizy słownika żywego języka rosyjskiego W. Dala typy zapożyczeń z języka ukraińskiego na rosyjski. Wyróżniono zapożyczenia pośrednie i bezpośrednie, kognaty, zapożyczenia leksykalno-semantyczne oraz semantyczne, zapożyczenia będące faktami rosyjskiego języka literackiego oraz te, które weszły w skład języka narodowego jako dialektyzmy. Ukrainizmy uzupełniły pasywną leksykę języka rosyjskiego w postaci archaizmów oraz historyzmów, jak również jego aktywną leksykę, z uwzględnieniem stylistycznej oraz stylowej różnorodności, reprezentując nominacje językowe właściwe i przenośne. Nie wszystkie fakty zapożyczeń z języka ukraińskiego odnotowane w słowniku W. Dala zostały formalnie potwierdzone we współczesnych słownikach języka rosyjskiego. Do ukrainizmów w języku rosyjskim należą przede wszystkim nominacje faktów ukraińskiej kultury i historii, leksemy, które „ujęzykowiają” kluczowe koncepty ukraińskiej mentalności, egzotyzmy oraz etnografizmy.

Słowa kluczowe: zapożyczenia, ukrainizm, znaczenie leksykalne, leksykografia, ekwiwalent, język ukraiński, język rosyjski.

WAYS, MEANS AND TYPES OF BORROWINGS FROM UKRAINIAN INTO RUSSIAN (based on V. Dahl Dictionary of the Russian Language)

TETIANA KOSMEDA

Adam Mickiewicz University, Poznań — Poland

HALYNA NAMACHYNSKA

Drohobych Ivan Franko State Pedagogical University, Drohobych — Ukraine 
ABSTRACT. The article focuses on the borrowings types from the Ukrainian language into the Russian one based on the analysis of V. Dahl Dictionary of the Russian language. The direct and indirect borrowings, the cognate borrowings, lexical, lexical-semantic borrowings and their semantic types; the borrowings that became the facts of the Russian literary language and the ones that enriched the Russian language as the dialect words have been singled out. The Ukrayinisms enriched the passive stratum of the Russian language because they nominate the archaisms as well as the active stratum of the Russian language taking into account the stylistic diversity and the diversity of style, representing the direct and indirect nominations. Not all the facts of borrowings from the Ukrainian language fixed by V. Dahl are registered in modern dictionaries of the Russian language. The nominations of the facts of Ukrainian culture, its history, lexemes that verbalize the key concepts of Ukrainian mentality, exotisms and ethnographisms belong to the borrowings-Ukrayinisms in the Russian language.

Key words: borrowing, Ukrayinism, lexical meaning, lexicography, equivalent, Ukrainian language, Russian language.

$\prod$ роблема запозичення належить до таких, що завжди $\epsilon$ актуальними в лінгвістиці, оскільки існує нагальна потреба вивчати явище запозичення як у синхронії, так і в діахронії, у системному поступі. Зауважимо, що запозичення 3 близькоспоріднених мов належать до складних проблем мовознавства. До цього часу не вивченим залишається процес запозичення з української мови в мову російську. Нагадаємо, що в словнику В. Даля зафіксовані запозичення в російську мову 3 малоросійської мови чи малоросійського наріччя, як у XIX ст. офіційно називали українську мову в Російській імперії.

Факт наявності запозичень 3 української мови в словнику живої російської мови В. Даля неодноразово відзначався в низці статей авторів цієї наукової розвідки ${ }^{1}$. До речі, $є$ свідчення, що В. Даль „спеціально готував і український словник, але зібрані матеріали (близько 8000 слів) залишилися неопублікованими"2. Однак на сьогодні доля цих матеріалів невідома.

Актуалізована проблема, як наголошувалося, не має повного опису в сучасному українському й російському мовознавстві, хоч окремі напрацювання, безперечно, є. Насамперед цієї проблеми торкалися такі мовознавці, як Л. Баранник, Т. Боброва, О. Владимирська, О. Журавльова, Л. Зотеєва, Г. Їжакевич, І. Кошман, Л. Крисін, Л. Романова, В. Собіннікова, В. Столбунова та ін.

Мета цієї наукової розвідки - запропонувати опис шляхів, характеру та типів запозичень з української мови в мову російську, що зафіксовані в тлумачному словнику живої російської мови В. Даля, а це значить, що аналізуються мовні факти к. XIX ст.

Зрозуміло, що в процесі запозичення в структурі перейнятих з української мови в мову російську слів відбулися відповідні зміни, запозичуватися могли лише окремі лексико-семантичні варіанти, і характер цих запозичень має різну природу й шляхи засвоєння. Щоб їх виявити, проведемо порівняльно-зіставний

${ }^{1}$ Див., напр.: Т. Космеда, Заборона української мови і унікальність ї̈ запозичувального потениіалу, [в:] Украјинистика и словенски свет, зборник научних радова: поводом 25 година украјинистике на Универзитету у Београду, главни уредник Људмила Попов ић, Београд 2017, с. 159-166; Г. Я. Намачи нсь ка Підтрунтя лексикографічної конщепиї̈ В. Даля: етнокультурний аспект, [в:] „Наукові праці” Чорноморського державного університету імені Петра Могили комплексу «Кисво-Могилянська академія». Серія «Філологія. Мовознавство», гол. ред. проф. Л. П. Клименко, Миколаїв 2016, вип. 266, т. 278, с. 88-91.

2 Див.: П. С елігей, Мовна свідомість: структура, типологія, виховання, Київ 2012, с. 36. 
аналіз семантичної структури окремих лексем-українізмів, зафіксованих у словнику живої російської мови В. Даля ${ }^{3}$, із сучасним тлумаченням цих лексем у словниках російської (БАС $\left.{ }^{4}\right)$ і української $\left(\mathrm{CУМ}^{5}\right)$ мов.

Проведений аналіз дає змогу констатувати наявність чотирьох груп лексем. Це українізми, зафіксовані в словнику В. Даля, однак 1) вони не ввійшли ані в БАС, ані в СУМ; 2) наявні в СУМi, однак не зафіксовані в БАСі, 3) увійшли в БАС, але не зафіксовані в СУМі; 4) зафіксовані і в БАСі, i в СУМі.

До першої групи (не ввійшли ані в БАС, ані в СУМ) відносимо такі лексеми, як: вибжа, дробушки, крез, кесь, сикава, скулочник, ошкварить, руля, шмарковать та ін. Це пояснюється тим, що В. Даль виокремлював, крім одиниць літературної мови, ще й пласти діалектизмів, сленгізмів й арготизмів, що самі по собі відпали й не потрапили в словники літературних російської та української мов.

До другої групи (містяться в СУМі, але не зафіксовані в БАСі), наприклад: бодня, брыдкий, варенуха, волочка, веселка, горобецьь, гоить, драбина, келеп, небога, окроп, покрытка, роля (рос. пахота), тямить, хист, шквыра та ін. Ці лексеми, очевидно, не стали фактами російської літературної мови.

До третьої групи (увійшли в БАС, але не зафіксовані в СУМі) належать лексеми подвалюк, отчинять, стрекаться та ін. Такі слова, вочевидь, вийшли з ужитку літературної української мови, однак залишилися в складі мови російської, зокрема лексема стрекаться репрезентує в СД два лексико-семантичні варіанти, але лише один із цих варіантів - українізм: „стыкаться, встречаться" (СД, т. 4, с. 338), що відтворено й у БАСі, однак при цьому подано примітку “простореч." і загалом семантична структура цієї лексеми розширилася до трьох лексико-семантичних варіантів, однак не за рахунок запозичень з української мови. Вочевидь, стилістичний параметр “простореч.” характерний і для значення цієї лексеми, що зафіксоване в СД. Наголосимо, що літературне просторіччя характеризується як факт “межі” між літературною мовою й народнорозмовною; це особливий стилістичний пласт мовних одиниць, що об'єднані експресивним забарвленням грубості чи фамільярності ${ }^{6}$ У цьому разі не відбулася зміна семантичної структури українізму. Зазначений процес можна подати у вигляді формули: СД = два ЛСВ, один з яких українізм. - БАС = три ЛСВ, але лише один 3 них українізм, як і в СД.

До цієї підгрупи відносимо й лексеми типу казать, втекать, cblnamb, гарный, розгукать, пика, сиротьл, неделя, икварить, фуга, купа, русалка, nапушный та ін. У СД окремі значення цих слів розглядаються як українізми. Однак, зважаючи на відображення значень цих слів у сучасній російській і українській мовах, їх можна розглядати як міжмовні омоніми. Наприклад, у словнику В. Даля подано такі значення лексеми втекать: „Втекать, втечь во что, вливать, течь, литься во что потоком, изливаться, вбегать струей, впадать \| млрс. бежать, даться бегу” (т. 1, с. 273). У БАСі, звісно, ця лексема не підтримує значення ‘бежать, даться бегу', а лише ‘вливаться во что-нибудь' (т. 1,

${ }^{3}$ В. И. Даль, Толковый словарь живого великорусского языка, в 4 томах, Москва 1981. Далі СД з указівкою на том і сторінку.

Словарь современного русского литературного языка, в 17 томах, под ред. В. И. Ч е р ныш ё в а, Москва-Ленинград 1950-1965. - Далі БАС із указівкою на том і сторінку.

5 Словник украӥнської мови, в 11 томах, ред. колег. І. К. Білоді д (гол.) та ін., Київ 19701980. - Далі СУМ з указівкою на том і сторінку.

${ }^{6}$ Див.: Лингвистический энциклопедический словарь, под. ред. В. Н. Ярцев в й, Москва 1990, с. 102. 
стлб. 903). Отже, маємо міжмовні омоніми: рос. втекать і укр. втікати (утікати) в значеннях '1) швидко відходити, відбігати, намагаючись уникнути небезпеки; 2) поспішати, відступати; 3) самовільно, потай іти, від’їжджати; 4) перен. швидко переміщатися, віддалятися; 5) позбавлятися кого-чого-небудь неприємного, небажаного; 6) десь подітися, пропасти; 7) припинити своє спільне життя 3 ким-небудь, покинути поружжя; 8) спливати (про воду)' (т. 10, с. 512-513). Утім, восьмий ЛСВ української мови частково співвідноситься з відповідним значенням лексеми втекать російської мови.

У словнику В. Даля лексема подволок репрезентована так: „Подволок, a, м. и подволока (млрс. и сев.) потолок” (т. 3, с. 357). У БАСі маємо: „Подволок, а, м. и подволока, и., ж. 1. Накат, свод; потолок. 2. В речи моряков - обшивка палубного настила со стороны внутренних помещений судна; полок" (т. 10, стлб. 291). У сучасній російській мові простежуємо збільшення кількості лексико-семантичних варіантів унаслідок актуалізації професіоналізму (мовлення моряків), тобто репрезентуємо формулу зміни структури цього слова в російській мові: СД = один ЛСВ-українізм. - БАС = два ЛСВ, один із яких українізм, як і в СД.

На думку В. Даля, лексема отчинять функціювала на півдні Росії, порівн.: „Отчинять, отчинить дверь, ворота, млрс. юж. кур. кал. тмб. твр.-ржв. отворить, отпереть” (т. 2, с. 767). У БАСі: „Отчинять, яю, яешь; несов.; отчинить, чиню, чигишь, сов. перех. Обл. Отворять, открывать” (т. 8, стлб. 1695). Отже, репрезентація лексеми отчинять в СД і БАСі збігається. Однак у БАСі міститься чітка вказівка на належність лексеми до нелітературного пласту російської мови, хоч указівки, що це українізм, немає.

В. Даль уважає українізмами й лексеми огудина, худоба, робить, cneвать, недужать, обрылнуть, тата, плугатар, узвар, дрюк, паляница, долонь, рудой, замордовать, реготать та ін. Подібні лексеми мають відповідники в російській літературній мові, порівн.: огудина - ботва, долонь - ладонь, спевать - nеть и т. д. Усі ці одиниці диференціюються за системою прагматичних параметрів, оскільки в СУМі всі вони з помітками обл. чи простор.

До четвертої групи (зафіксовані і в БАСi, i в СУМi) належать, напр., такі лексеми, як: атама́н, айва, бублик, булава, войт, гетьман, дума, замордовать, каба́ка, казать, козак, недужать, оселедец, паляница, плахта, плугатар, реготать, робить, сват, свита, спивать, староста, сыпать, треба, уладить, универсал, худоба, чумак, чути, швачка, шкварить, шорник, явор та ін. Серед цих одиниць лише деякі в БАСі однозначно визнаються як запозичені з української мови, це, зокрема, такі: бублик, каба́ка, нехай, треба, чумак, чутно.

Лексема нехай зафіксована в СД в значенні 'пусть, нехай' (т. 4, с. 678). Простежуємо факт запозичення-українізму, що зафіксовано і в БАСі, однак БАС дає вказівку на те, що лексема-українізм належить до російського діалектного мовлення (“обл.”). У БАСі наявний поклик на СД, порівн.: „Нехай, частица. Обл. Пусть - Даль. Слов.: нехай. - укр. нехай” (т. 7, стлб. 1261). Лексема нехай не стала фактом літературної російської мови. У СУМі маємо репрезентацію системи ЛСВ значення цього слова. Зауважується, що лексема належить до стилістичного пласту розмовної лексики, порівн.: „Нехай, розм. 1. част. у спол. 3 дієсловом 3 особи одн. або мн. теп. або майб. часів. Уживається для утворення аналітичної форми наказового способу 3 особи дієслова, що виражає: а) наказ, спонукання; б) дозвіл, згоду, припущення; в) побажання. 2. част. Уживається при вираженні згоди з чим-небудь. 3. част., у сполуч. 3 дієсловом 1 ос. майб. ч. 
Уживається при вираженні якого-небудь побажання, готовності, прагнення до чогось” (т. 5. с. 348). Отже, поданий вище аналіз можна репрезентувати у вигляді формули: СД = один ЛСВ-українізм - БАС = один ЛСВ-українізм. $\mathbf{C У М ~ = ~ т р и ~ Л С В . ~ У к р а і ̈ н і з м ~ р о с і и ̆ с ь к о і ̈ ~ м о в и ~ н е х а и ̆ ~ м а є ~ р о с і и ̆ с ь к и и ̆ ~ в і д п о в і д н и к ~}$ nycmь. Очевидно, запозичена лексема-українізм не пройшла повної адаптації в російській мові. Пусть функціює в російській літературній мові, а нехай у діалектному мовленні (помітка “обл.”). Можливо, у БАСі лексема нехай не набула повного опису, що пов'язано з панівною в російському мовознавстві дорадянського й радянського періодів тенденцією (це простежуємо до сьогодні ${ }^{7}$ ) приниження статусу української мови загалом, заперечення фактів запозичення з української мови.

Утім, простежуємо й факти запозичень-українізмів, зафіксованих і в СД, i в БАСі із засвідченням належності слова до складу російської літературної мови, тобто в цьому разі відбувається повна адаптація лексеми в російську літературну мову, хоч і за певної диференціації структури значення. Такі випадки стосуються переважно екзотизмів чи етнографізмів. Прикладом слугує доля лексеми бублик, порівн.: СД - „хлебное кольцо, крендель, большой баранок, пшеничное тесто кольцом, сваренное в воде, а потом запеченное" (т. 1, с. 135); БАС: „круглый крендель, баранка (южное и украинское)” (т. 1, стлб. 663). У тлумачному словнику російської мови, що укладений С. Ожеговим, подано більш широку інформацію; надаються фразеологізми із зазначеною лексемою, порівн.: „большая толстая баранка из некрутого теста. Бублик с маком. Дырка от бублика (о чем-нибудь пустом, лишенном всякого содержания); разг. шутл. // прил. бубликовый, -ая, -ое и бубличный, -ая, -ое"8. Порівн. семантичну структуру російської лексеми баранка, що є в російській мові синонімом до українізму бублик. „Баранка, -и, ж. 1. Пшеничный хлебец в виде кольца из заварного крутого теста. 2. Перен. Рулевое колесо автомобиля (прост.). Сесть за баранку; крутить баранку" (СО, с. 42). Семантична структура цього слова містить два ЛСВ - пряме й переносне. Те саме простежуємо в СУМі стосовно української лексеми бублик, порівн.: „Бублик, -а, ч. 1. Круглий крендель із заварного тіста, що має форму кільця. Держати хвіст бубликом - бути бадьорим, життєрадісним. 2. Розм. Рульове колесо автомашини" (т. 1, с. 224). Подамо формулу репрезентації структури слова бублик в актуалізованих тлумачних словниках: СД = один ЛСВ-українізм. - БАС $=$ один ЛСВ-українізм. - СО = один ЛСВукраїнізм. - СУМ $=2$ ЛСВ.

Під час порівняння семантичної структури власне російського слова баран$\kappa a$ й російського запозичення-українізму бублик можна стверджувати, що простежуємо певну диференціацію структури запозиченого й споконвічного значень слів: бублик - це не просто баранка, а „баранка большая, толстая, из некрутого теста". Лексема бублик, крім того, увійшла до складу фразеологізмів російської мови, запозичених з мови української. Лексема набула цілком самостійного значення, повністю адаптувалася в російській мові.

Трапляються випадки, коли українізм російської мови належить до когнат - спільного слов' янського лексичного пласту. Такого типу запозичення це повторне входження в російську мову лексеми, що колись була йй притаманна. Українські лексеми треба, потрібно в СД тлумачаться як: „Треба нар. црк.

${ }^{7}$ Див. про це, напр.: Т. Ко смеда, Лингвокалейдоскоп: живые речевые процессы (на материале русского и украинского языков), Саарбрюккен 2017.

8 С. И. Ожегов, Словарь русского языка, под. ред. Н. Ю. Шведовой, 22-е изд., Москва 1990, с. 66. - Далі СО з указівкою на том і сторінку. 
или запад. млрс. потребно, надобно, нужно, необходимо, должно, следует, надлежит, надо" (т. 4, с. 427). У СД подано також іменник треба як омонім до прислівника треба, порівн.: „Треба, ж, жертва, приношенье, жертвоприношение” (т. 4, с. 427). Цей іменник за походженням має спільний корінь із прислівником. БАС фіксує ті самі омонімічні значення, хоч указує на діалектне використання прислівника треба. Подаються також довідки зі словників І. Срезневського, П. Беринди, В. Даля та Д. Ушакова, порівн.: „Треба, и, ж. В православии: служебный обряд, совершаемый по просьбе верующих (напр. крестины, венчанье, панихида, исповедь” и „Треба, безл. сказ. Обл. требуется, нужно, необходимо. - Срезневский: трђбъ, Берында, Лекс., 1672: требъ есть, Даль, Слов.: треба, требе; Ушак. Толк. слов. 1940 - треба. - Укр. треба" (т. 15, стлб. 849-850). А в СУМі маємо: „Треба, присуд. сл., також з інфініт. Потрібно, необхідно, слід” (т. 10, с. 241). Отже, опишемо результат порівняльного аналізу подання лексеми треба (прислівникова форма) в актуалізованих словниках у вигляді формули: СД = один ЛСВ-українізм. - БАС = один ЛСВ-українізм. - СУМ = один ЛСВ.

Порівняння значень лексеми треба в російській та українській мовах, що зафіксовані в системі тлумачних словників, наявність омонімії, а також спільнокореневих слів у російській мові, як-от: требовать, требование та ін., що, вочевидь, не утворені від української лексеми треба (рос. 'нужно, необходимо'), дає право висловити думку, що це слово належить до спільного праслов’ янського лексичного фонду. Отже, із української мови в російську запозичено лексему треба в значенні 'требуется, нужно, необходимо' .

B. Даль пропонує таке визначення лексеми кабака: „Тыква. Cucurbitamelopepos maxima; ошибочно кабак” (т. 2, с. 69). У БАСі маємо: „Кабак, а, м. Обл. Тыква. ... - Опыт обл. слов. Акад. 1852; кабак - укр. кабак (из турецк.)” (т. 5, стлб. 614-615). У СУМі - „Кабак, а. ч. діал. Гарбуз. ... Давати кабака те саме, що Давати гарбуза...” (т. 4, с. 63). Як бачимо, у БАСі зафіксовано, що зазначене слово запозичене з української мови, хоч є вказівка на діалектне його використання. Крім того, це слово фактично запозичене українською мовою 3 турецької мови, тому українська мова в цьому разі $є$ посередником запозичення, хоч фактом власне літературної російської мови це слово не стало, як належить воно до діалектного мовлення і в системі української мови. Синоніми кабака й тыква розрізняються сферою вживання. Отже, у цьому разі фактично не виокремлюємо змін у використанні слова кабака як у словнику В. Даля, так і в БАСі та СУМi.

Об'єктом запозичення, безперечно, є лексеми-екзотизми сучасної української мови. У цьому разі запозичується окремий лексико-семантичний варіант. Як ілюстрацію цього розглянемо “долю” лексеми чумак. У В. Даля маємо: „Чумак, м. каз. прм. целовальник, кабачник, сидельщик в кабаке или помощник его || юж. нврс. сар. млрс. протяжной, извозчик на волах; в былое время отвозили в Крым и на Дон хлеб, а брали рыбу и соль; этот промысел ныне сильно упал; || чумак и чумилка пск. замарашка, чумазый” (т. 4, с. 614). Порівняймо цю інформацію з наданою в БАСі: „Чумак, а, м. В старину на Украине - крестьянин, возивший на волах в Крым хлеб и др. сельскохозяйственные продукты, а оттуда соль, рыбу и прочие товары для продажи. Слов. Акад. 1794: чу́мак и чума́к (прислужник целовальника в питейном доме); Слов. Акад. 1847: чумак. - Укр. чумак” (т. 17, стлб. 1198). СУМ фіксує таке значення: „Чумак, а, ч. 1. На Україні в 15-19 ст. - візник і торговець, який перевозив на волах хліб, сіль, рибу та інші 
товари для продажу. 2. Український народний танець” (т. 11, с. 382-383). Отже, як бачимо, у цьому разі можемо подати таку формулу: СД = три ЛСВ, з яких лише другий ЛСВ - українізм. - БАС = один ЛСВ-українізм, що = другому ЛСВ СД. - СУМ = один ЛСВ, що збігається із другим ЛСВ-українізмом СД і першим ЛСВ-українізмом БАСу. У БАСі збереглося запозичення з української мови, однак порівняно зі словником В. Даля простежуємо звуження значення, натомість у СУМі маємо розширення семантики: обидва значення окреслюють екзотизми української лінгвокультури. Порівн. також назву сузір'я Чумацьький Шлях.

У цьому разі маємо факт запозичення з української мови: із трьох ЛСВ значення лексеми в російській мові зберігся власне українізм, однак сьогодні це слово має звужену сферу вживання, оскільки належить до етнографізмів. Цю лексему вважаємо належною до безеквівалентної лексики української мови, вона номінує факт української культури й не має в російській мові синонімів.

Лексичне значення слова чутно виначено в словнику В. Даля як 'слышно' (т. 4, с. 616), у БАСі маємо: „Чутно, безл, сказ. обл. и в речи украинца сльшино... - Даль, слов.: чутно. - Укр. чутно” (т. 17, стлб, 1209). Зазначена лексема репрезентує дієслівну форму на -но, яка не характерна для російської мови, що й підтверджує факт впливу української мови. Порівн. у СУМі: „Чути, чую, чуєш, недок. 1. Перех. Сприймати за допомогою органів слуху які-небудь звуки. 2. Непер. Мати слух. 3. Перех. Мати які-небудь дані, відомості про кого-, що-небудь, знати про кого-небудь з розмов, чуток і т. ін. Те саме, що відчувати. 5. Виявляти, розпізнавати, знаходити кого-, що-небудь за допомогою органів нюху. 6. У знач. присл. Чутно, видно. 7. У формі 2 особ. тепр. ч. Чуєш, чуєте і рідко мин. ч. Чув. Уживається для підкреслення сказаного, звернення уваги на кого-, що-небудь" (т. 11, с. 386). У цьому разі формула-аналіз має такий вигляд: СД = один ЛСВукраїнізм. - БАС = один ЛСВ-українізм. - СУМ = сім ЛСВ, із яких шостий ЛСВ = ЛСВ-українізму СД і БАСу.

У сучасній російській мові простежуємо наявність синонімії чутно сльшшно. Як видається, наявність у російській мові спільнокореневих слів чутье, чуткий, чуять (рос. 'ощущать') дає право стверджувати, що укр. чутно належить до когнат, що розійшлися значеннями в українській і російській мовах, а згодом російська мова запозичила розглядувану давню дієслівну форму й відповідне значення. Як бачимо, українська мова розвинула для цього слова низку лексико-семантичних варіантів, значно розширивши його семантичну структуру.

Окрему групу складають лексеми, що безпосередньо називають предмети українського побуту, поняття культури, відповідні реалії України, однак запозичені в українську мову з інших мов. Українська мова освоїла подібні слова й саме через неї лексеми перейшли в російську літературну мову. До цієї групи лексики відносяться, напр.: атаман, булава, войт, гетман, дума, казак, оселедеи, плахта, сват, свита, староста, универсал та ін.

У тлумачному словнику В. Даля слово универсал репрезентовано в значенні 'грамота малороссийского гетмана' (т. 4, с. 498); у БАСі - це „польский королевский или украинский гетманский указ, имевший характер манифеста. Яновский, Нов. словотолк. 1806: универсалы; Даль, слов.: универсал — польск. Universal от лат. Universalis - всеобщий” (т. 16, стлб. 562). У СУМі репрезентовано таку семантичну структуру цього слова 3 поміткою icmop.: „1. Розпорядчий акт адміністративно-політичного характеру польських королів та україн- 
ських гетьманів (іноді представників центральної старшини) у 17-18 ст. 2. Звернення декларативно-програмного характеру, опубліковані в 1917-1918 роках Центральною радою" (т. 10, с. 449-450). Отже, зіставний аналіз репрезентації структури лексичного значення в актуалізованих словниках дає змогу подати формулу: СД = один ЛСВ-українізм. - БАС = один ЛСВ, що збігається з ЛСВ у СД. - СУМ = два ЛСВ, із яких перший ЛСВ збігається 3 поданими ЛСВ у СД і в БАСі. Ця лексема латинського походження, увійшла в українську мову через польську і, відповідно, з неї в мову російську. Значення лексеми відображає історію України, що підтверджено параметральною позначкою icmop. Саме в такому значенні це слово й функціює в сучасній російській мові.

У словнику В. Даля лексема оселедец репрезентована так: „Оселедец, м., млрс. чуприна, чуб, коса или косма на темени головы $\|$ Волжская сельдь” (т. 2, c. 695). У СУМі аналогічно маємо два лексико-семантичні варіанти, однак простежуємо перерозподіл ЛСВ, порівн.: „1. Невелика промислова риба, яку вживають у засоленому або копченому вигляді. 2. Старовинна чоловіча зачіска у вигляді довгого пасма волосся на оголеній голові (перев. у козаків); чуприна" (т. 5, с. 758). У сучасну літературну російську мову з української мови запозичено відповідний лексико-семантичний варіант, порівн.: „Оселедец, дца, м. Длинный чуб на темени бритой головы у украинцев (в старину)" (т. 8, стлб. 1086). Подамо формулу, що відображає характер співвідношення значень цього слова у відповідних словниках: СД = два ЛСВ, перший з яких українізм. - БАС = два ЛСВ, перший $з$ яких українізм, що збігається 3 тлумаченням у СД. - СУМ = два ЛСВ, другий з яких збігасться 3 першим ЛСВ СД і БАСу, а перший ЛСВ, відповідно, збігасться з другим ЛСВ СД. Як бачимо, зазначена лексема пройшла відповідну адаптацію в російській мові й сьогодні зафіксована виключно як українізм, хоч і належить до застарілого лексичного пласту мови.

Лексема войт подана в словнику В. Даля з репрезентацією одного лексикосемантичного варіанта значення слова, порівн.: „Войт, м. юж. и зап. Начально градской глава (был напр. в Киеве), ныне старшина, местами городской старшина; род полицейского тысяцкого или пятисотского в посадах или местечках или над несколькими сотскими, местами деревенский староста или даже наряженный с рабочими в поле десятский..." (т. 1, с. 231). БАС фіксує таку модель: „Войт, а, м. истор. Выборное или назначавшееся должностное лицо в средневековых городах Польши, Украины и Белоруссии. Устар. Деревенский староста. - др.-русск. войтъ, Слов. Акад. 1847: войт, войтов, войтовский, войтовство; Даль, Слов. войтовский, войтовать. польск. wójt, из нем. Vogt, от лат. Vocatus - ризванный” (т. 1, стлб. 603). У СУМі — „Війт, а, ч. Керівник місцевого (міського чи сільського) управління або самоврядування в середньовічній Німеччині, Литовському князівстві, Польщі та Україні 15-18 ст. // У Західній Україні та Польщі (до 1950 р.) — голова військової управи" (т. 1, с. 670). Відтворимо аналіз зіставлення у вигляді формули: СД = один ЛСВ (широке значення). - БАС = один ЛСВ, що частково збігасться зі значенням, поданим у СД. - БАС = один ЛСВ з двома відтінками значення, що частково відповідають значенням, репрезентованим у СД і БАСі. Зазначена лексема походить 3 латинської мови, розвинула своє значення в німецькій мові, звідки була запозичена польською мовою, а з неї адаптувалася в українській мові й згодом з української перейшла в російську, де сьогодні слугує для позначення українських реалій з поміткою істор. 
Слово гетман у В. Даля трактується як 'звание бывшего начальника малороссийского казачьего войска, войсковой атаман' (т. 1, с. 349). У БАСі маємо: „Гетман, а, м. Истор. 1. Выборный начальник Запорожской Сечи в 16-17 вв.; также верховный правитель присоединившейся в 1654 г. к России Украины (до 1764). 2. Командующий войсками в польско-литовском государстве 16-17 вв.” (т. 3, стлб. 86). У СУМі - це „1. В 16 ст. — виборний ватажок козацького війська Запорізької Січі з 17 ст. до 1764 р. — начальник козацького війська та правитель України. 2. Головнокомандуючий збройними силами ПольськоЛитовської держави в 16-18 ст.” (т. 2, с. 58). На основі зіставлення подаємо формулу-аналіз: СД = один ЛСВ. - БАС = два ЛСВ, перший з яких відповідає першому ЛСВ, репрезентованому в СД, і першому ЛСВ СУМа; другий ЛСВ дорівнюс другому ЛСВ, репрезентованому в СУМі. - СУМ = два ЛСВ. У сучасних словниках української й російської літературних мов відображено розширення семантики цього слова. Сучасна російська мова звузила сферу використання лексеми - міститься помітка істор. Зауважимо також, що в російську мову слово ввійшло з української, хоч гетман первинно походить 3 німецької мови - Hauptman ('начальник'); слово було поширене й у польській мові, порівн. Hetman, звідки у формі гетьман перейшло в мову українську й репрезентує поняття, характерне для української історії.

Слово казак у словнику В. Даля зафіксовано зі значеннями '1. Войсковой обыватель, поселенный воин, принадлежащий к особому сословию казаков, легкого конного войска, в своей одежде и вооружении. Есть и пешие казаки, в числе которых более известны черноморские пластуны. 2. Малорусские казаки те же крестьяне и ставят рекрут на своих правах' (т. 2, с. 72). У БАСі маємо: „Казак, а. мн. казаки́, о́в и каза́ки, ов, м. 1. В русском государстве 15-17 вв.вольный человек из бежавших на окраины русского государства (Дон., Яик., Запорожье) крепостных крестьян, холопов и городской бедноты. 2. В дореволюционной России с 18 в. - представитель военного сословия - уроженец войсковых областей (войска Донского, Кубанского, Тверского, Оренбургского), обязанных нести службу за льготное пользование землей. 3. Крестьянин, уроженец бывших войсковых областей” (т. 5, стлб. 654). У СУМі ж маємо таку семантичну модель: „Козак, а, ч. 1. На Україні в 15-18 ст. - вільна людина з кріпосних селян або міської бідноти, що втекла на південні землі України й брала участь у визвольній боротьбі проти татаро-турецьких і польських загарбників; нащадок такої людини. // У Росії 16-18 ст. — вільна людина, що втекла на окраїни держави (Дон, Яик). 2. У дореволюційній Росії з 18 ст. - представник військового стану, уродженець військових областей (Кубанської, Оренбурзької, Донського війська), який був зобов'язаний служити в армії за пільгове користування землею. 3. Уродженець колишніх військових областей. 4. Парубок, юнак взагалі. 5. Розм. Відважний, завзятий, хоробрий чоловік, молодець. 6. Те саме, що козачок” (т. 4, с. 209). Як бачимо, зазначена лексема розширила семантичну структуру свого значення власне в українській мові, де маємо шість ЛСВ, хоч первинно й запозичена $з$ тюркської групи мов. Зіставний аналіз показує, що в БАСі подано не зовсім точний опис, оскільки в російській мові це слово функціонувало й у лексико-семантичних варіантах, запозичених з української лінгвокультури завдяки художнім текстам українських письменників, які писали російською мовою, та у творах російських письменників, які писали про українську бувальщину. Однак, якщо словник В. Даля ще дає вказівку на специфіку вживання цієї лексеми щодо українських реалій, то БАС цього не відо- 
бражає. Тому вважаємо, що насправді три останні значення лексеми козак в російській мові використовувалися як українізми, однак це не показано в словнику. Для підтвердження наведемо ідіому російської мови, що запозичена з української мови й нині активно функціює в російській мові, порівн.: Терпи, казак, атаманом будешь. Адже в цьому разі лексема казак вжита в значеннях, власне, 'парубок, юнак взагалі' чи 'відважний, завзятий, хоробрий чоловік, молодець', а не в тих значеннях, що зафіксовані в БАСі. Порівн. також контекст: - Неразумная голова, — говорил ему Тарас. - Терпи, козак, - атаман будешь! Не тот ещё добрый воин, кто не потерял духа в важном деле, а тот добрый воин, кто и на безделье не соскучит, кто всё вытерпит, и хоть ему что хочь, а он всётаки поставит на своём (Н. Гоголь, Тарас Бульба); [Андрей Титыч: ] Прихожу я домой-с..., а тятенька вдруг ко мне: "Что, говорит, ты шляешься, как саврас без уздь!! Собирайся, говорит, ехать невесту смотреть!" Как тут жить! [Досужев:] Что делать-то! Терпи, казак, атаманом будешь! (А. Островский. Тяжелые дни); Григорий Мелехов стоял рядом с Коршуновым Митькой, - Сапог ногу жмет, терпения нету, - жаловался Митька. - Терпи, атаманом будешь (М. Шолохов. Тихий Дон).

У цьому разі не будемо репрезентувати формулу на основі аналізу, оскільки вона не відбиватиме реальної картини, тобто лексико-семантичні варіанти значення лексеми казак насправді запозичені з української мови, у словниках не відображені.

Слово плахта в словнику В. Даля подано так: „Твр. Головной золотканный платок || Кал. Кур. юбка, понева; || млр. нврс. шерстяной клетчатый платок, обертываемый женщинами вокруг пояса, заместо юбки” (т. 3, с. 122). БАС дещо уточнює значення, проектуючи його виключно на українську культуру, порівн.: „Плахта́, а, ж. Кустарная украинская шерстяная или бумажная ткань с узорами из квадратов, полос, звездочек и т. п. 2. Украинская национальная одежда из четырехугольного отреза такой ткани, обертываемого вокруг талии, заменяющая юбку” (т. 9, стлб. 1347). У СУМі маємо: „Плахта, и, Ж. 1. Жіночий одяг типу спідниці, зроблений із двох зшитих до половини полотнищ переважно вовняної картатої тканини. 2. Картата декоративна тканина. 3. Покривало або килим з такої тканини" (т. 6, с. 571). Зіставлення словникових статей показує, що в СД зафіксовано ЛСВ, що вийшли з ужитку, однак актуалізувався власне українізм. В українській мові слово розширило семантику до трьох ЛСВ. Якщо порівняти структуру значення цього слова в БАСі і СУМi, то бачимо, що порядок слідування ЛСВ не збігається: перший ЛСВ СУМу відповідає другому ЛСВ БАСу i, навпаки, другий ЛСВ СУМу відповідає першому ЛСВ БАСу. Якщо лексему плахта вважати українізмом російської мови, то й порядок слідування ЛСВ повинен у словнику російської мови відповідати порядку, репрезентованому в СУМі.

У словнику В. Даля зафіксована лексема староста з указівкою на залежність значення від наголосу, тобто ста́роста 'вообще старшина, большак, начальник по выбору или поставленный, из того же сословия' і cmapócma 'зап. польск. владелец... || млрс. сват, засылаемый к родителям невесты’ (т. 4, с. 318). Полонізм і українізм, як бачимо, відмінні за значенням. У БАСі також зафіксовано подвійний наголос, однак лексеми подані як омоніми, порівн.: „Ста́роста, Ы, м. 1. В дорев. России - выборное или назначаемое должностное лицо, выполняющее административно-полицейские обязанности в сельском обществе. 2. Выборное или назначаемое лицо для ведения какого-либо небольшо- 
го общества, коллектива. - Срезневский: ста́роста; Поликарпов, Лекс. 1704: ста́роста” (т. 14, стлб. 762) і „Старо́ста, ы, м. В феодальной Польше - представитель короля в воеводстве или повете. - Даль, Слов.: старо́ста. Польск. starosta" (т. 14, стлб. 762-763). У СУМі всі наведені вище значення репрезентовані як окремі ЛСВ з наголосом на першому складі, порівн.: „Ста́роста, и, ч. 1. На Україні, в Польщі та Литовському князівстві (15-18 ст.) - керівник місцевого, міського чи сільського управління або самоврядування, війт. 2. У Західній Україні (до 1939 р.) - начальник, голова повіту. 3. У Царській Росії — голова сільської громади. 4. Виборна або призначена особа для ведення справ якого-небудь громадського колективу, товариства і т. ін. // У середніх та вищих учбових закладах - призначена чи обрана особа, що очолює клас, курс, групу i т. ін. 5. Особа, що сватає жениха нареченій або наречену женихові. Засилати (заслати, присилати, прислати, слати і т. ін.) старостів - посилати старостів до дівчини, жінки або її батьків, просячи згоди на шлюб; свататися" (т. 9, с. 662). Отже, виразно простежуємо, що п'ятий ЛСВ слова ста́роста 'особа, що сватає жениха нареченій або наречену женихові' - українізм російської мови, що відображено в текстах художньої літератури на українську тематику, які були написані в XIX ст., насамперед у творах М. Гоголя.

Слово булава в словнику В. Даля подано як: „набалдашник, головка; || палица как оружие, дубинка или кистень; $\|$ такое же оружие как знак начальственной власти, жезл, бунчук, сохранившийся при Донском войске; быть при булаве, при атамане, при штабе. У малороссийских атаманов была булава шестопер” (т. 1, с. 139). У БАСі: „Булава́, ы́, ж. 1. Спорт. Гладкий деревянный ручной снаряд с утолщением и набалдашником, употребляемый в гимнастических упражнениях. 2. Устар. Длинная палка с шаровидным набалдашником, служившая принадлежностью парадной одежды швейцара у входа в крупные учреждения и частные аристократические дома Царской России. - Истор. Жезл с шаровидным набалдашником, служивший знаком гетманской власти у казацких атаманов. 3. Истор. Короткая палица с утолщением на верхнем конце или с шаровидным набалдашником, служившая боевым оружием в древней Руси и у других древних народов. - Др.-русс. боулава; Вейсманнов Лекс. 1731 с. 189: булава; Слов Акад. 1789: булава" (т. 1, стлб. 534). Як бачимо, у БАСі вже немає вказівки на факт запозичення з української мови, хоч відповідний ЛСВ зберігся. Лексема розширила значення за рахунок з'яви терміна зі сфери спорту. У СУМі також зберігається історизм, порівн.: „Булава́, и, ж. 1. Кулясте потовщення на кінці палиці і т. ін. 2. Іст. Палиця з кулястим потовщенням на кінці, яка була колись військовою зброєю // Така ж палиця як символ влади. 3. Заст. Довга палиця 3 кулею зверху - річ, належна до парадної форми швейцара в установах і аристократичних домах дореволюційної Росії' (т. 1, с. 253). Отже, як бачимо, ЛСВ-українізм зберігся в російській мові ('жезл с шаровидным набалдашником, служивший знаком гетманской власти у казацких атаманов’) і належить до пасивного пласту лексики - історизмів.

Слово свита також зафіксовано у В. Даля як українізм, порівн.: 'млрс. широкая запашная долгая одежда без перехвата, обычно с видлогою, кобеняком, кобкою, куколем' (т. 4, с.148). У БАСі втрачається вказівка на приналежність одягу виключно українцям, порівн.: 'род верхней народной мужской и женской одежды у русских, украинцев и белоруссов', крім того, значення слова розширилося, оскільки воно набуло ще один ЛСВ порівняно із семантичною структурою, що наявна в СД, з поміткою розм.: 'вообще какая-либо одежда' (т. 13, 
стлб. 389-380). В українській мові лексема має дещо інше значення. Крім основного ('старовинний довгополий верхній одяг, звичайно з домотканого грубого сукна, одяг убогих людей'), додано відтінок значення 'бідний селянин у дореволюційній Росії' (т. 9, с. 76). У цьому разі маємо механізм творення значення за моделлю метонімії. Як видається, В. Даль мав рацію, коли виокремив семантичний українізм. Сьогодні ця лексема у всіх значеннях належить до пасивного пласту лексики як в українській, так і в російській мовах.

Стосовно лексеми сват В. Даль також подає вказівку на українське походження одного зі значень, порівн.: „Сват м. Тот, кто идет сватать невесту по поручению жениха или родителей его, более в Малороссии, а у нас делает это сваха. || сват м. сватья ж. Родители молодых или родственники друг друга взаимно зовут сватами, сватьями" (т. 4, с. 145). У БАСі ця вказівка на семантичний українізм зникає, закцентована функція свата і свахи в російській та українькій культурах нейтралізується, порівн.: „1. Человек, сватающий жениха невесте или невесту жениху. 2. Отец или родственник одного из супругов по отношению к родителям или родственникам другого супруга" (т. 13, стлб. 269-270). У зв'язку зі значущістю концепту сват для української лінгвокультури в українській мові розвинулася семантика цього слова, відбулося розширення внаслідок виникнення переносного значення, порівн.: „1. Людина, яка за дорученням того, хто хоче одружитися, або його рідних, сватає обрану особу; староста у весільному обряді. 2. Батько або родич одного з подружжя щодо батьків або родичів другого. 3. Перен. розм. Людина, що посилено пропонує когось на якусь посаду, умовляє взятися за якусь справу" (т. 9. с. 66).

Значення лексеми атаман у словнику В. Даля подано як запозичення з української мови, порівн.: „Атама́н м. (малорус. ота́ман и ге́тман, нем. Hauptmann) начально значило: предводитель шайки вольницы; затем выбранный старшина, голова козачьей общины... На Украине гетман означало войскового, а отаман куренного начальника; у запорожцев были куренные (сельские) отаманы и один над ними кошевой отаман, подчиненный гетману, в малоросском и новоросском крае отаманом зовут сельского старшину, выборного, старосту, также старшего пастуха или чабана, большака рыболовной ватаги" (т. 1, с. 28). Зауважимо, що В. Даль виокремив й особливості вимови цього слова в українській мові.

У БАСі інакше відображено семантичну структуру цієї лексеми: „Атаман, a, м. 1. Дорев. Назначаемый или выборный начальник (в казачьих войсках и селениях), обычно происходивший из зажиточной казачьей верхушки. Истор. В эпоху феодализма у казаков - выборный начальник вольных военных дружин. 2. В эпоху гражданской войны - главарь белогвардейской банды. 3. Устар. Главарь разбойничьей или воровской шайки” (т. 1, стлб. 253). Як бачимо, у БАСі не подана інформація про характер запозичення лексеми. Наведені значення належать до пасивного лексичного пласту російської мови - історизмів чи архаїзмів, хоч, як зауважувалося раніше, прислів'я Терпи, казак, - атаманом будешь досить поширене в сучасному мовленні росіян.

У СУМі отаман - це „1. Іст. Виборний або призначений ватажок козацького війська // Представник козацької адміністрації у населених пунктах на Україні в 17-18 ст. 2. У дореволюційній Росії - начальник козачих військ і поселень, що виконував військові, поліцейські та адміністративні функції. 3. У роки громадянської війни - верховода контрреволюційних банд. 4. Заст. Ватажок, керівник. // Той, хто очолює яку-небудь виборну і т. ін. групу людей” (т. 5, с. 801). 
Якщо порівняємо семантичну структуру цього слова в наведених словниках, то бачимо, що в російській мові в БАСі відбувся перерозподіл значень порівняно з СД. БАС відтворює специфіку значення, що є запозиченням з української мови, тобто перший ЛСВ і є семантичним українізмом. Найбільш широка структура значень цього слова репрезентована в СУМі, що засвідчує важливість лексеми для української лінгвокультури, хоч і в СУМі маємо значення, що переважно належать до пасивного пласту лексики, однак концептуальне навантаження цієї лексеми важливе для ментальності українців.

Не менш важливий для концептуальної картини світу українців і концепт дума. У В. Даля відтворено семантичну структуру слова дума так: „Ду́ма, ду́мка, ду́мочка, ду́мушка ж. действие по знач. глагола. || Дума и самый предмет, что задумано, мысль, мечта, забота, что или о чем кто думает, мыслит, что кого на уме... || Лирическое стихотворение в роде баллады || Собранье чинов, для каких-либо дел” (т. 1, с. 500). У БАСі семантичний українізм репрезентовано в другому ЛСВ, порівн.: „1. Мысль, размышление. 2. Род украинской народной исторической песни. 3. В старое время и в Царской России: название некоторых государственных учреждений" (т. 3, стлб. 185). Те саме значення відбито і в СУМі, однак те значення (другий ЛСВ), що стало семантичним українізмом російської мови, репрезентовано точніше, ніж в словнику російської мови, порівн.: „2. Літ. народна ліро-епічна пісня, що виконується сольним співом-декламацією у супроводі кобзи, бандури або ліри і має нерівномірну будову вірша" (т. 2, с. 434). Наголосимо, що лексема дума настільки важлива для української концептуальної картини світу, що містить особливу конотацію. В. Даль наводить російський еквівалент до слова дума - це мыслль, однак від мысль можна утворити зневажливе мыслишка, чого не дає змоги зробити прагматика слова дума (лише думка, думочка), оскільки „основа слова думка за своєю природою не може поєднуватися із суфіксами негативної оцінки, вираження зневаги", В українській поезії ця лексема має високий прагматичний ореол, що підкріплюють тексти українських письменників, насамперед Т. Шевчен$\mathrm{\kappa a}^{10}$. Очевидно, дума, думка належать до констант української культури, ключових концептів української ментальності, як і деякі інші українізми російської мови, наведені вище.

Отже, як було показано, у словнику В. Даля зафіксовано чимало запозичень 3 української мови, що ввійшли в російську мову а) безпосередньо з української мови чи б) опосередковано, тобто українська мова запозичила лексеми з інших мов, а згодом виконала функцію донора стосовно мови російської: подібні одиниці відображають передусім українські реалії - українську культуру чи іiі історію, належать до групи екзотичної лексики, позначають етнографізми.

Крім того, в окремих випадках простежуємо актуалізацію когнат, тобто лексем, що належали до спільного (давньослов'янського) пласту лексики, значення яких у російській й українській мовах “розійшлися”: хоч форма, лексична оболонка частково збереглася в обох мовах, проте згодом у російську мову з української було запозичено значення, що належить при спільній зовнішній формі лексеми лише українській мові, тобто відбулося розширення семантики лексеми російської мови.

${ }^{9}$ T. Космеда, Ego i Alter Ego Tapaca Шевченка в комунікативному просторі щоденникового дискурсу, Дрогобич 2012, с. 108.

${ }^{10}$ Див. докл. про це: Там с ам о, с. 101-109. 
Запозичувалася українська лексема загалом у іiі повній семантичній структурі чи частково, тобто лише окремі ЛСВ слова української мови.

Українізми поповнили як активний, так і пасивний запас російської мови (історизми та архаїзми), крім того, вони ввійшли не лише в склад літературної мови, але й у національний іiі склад як діалектні одиниці.

Запозичені прямі й переносні значення з урахуванням особливостей семантики й прагматики, стильових і стилістичних параметрів.

На часі проблема укладання словника українізмів російської мови.

\section{Список використаної літератури}

Даль В. И., Толковый словарь живого великорусского языка, в 4 томах, Москва 1981.

Космеда Т., Заборона української мови і унікальність ї̈ запозичувального потенщіалу,

[в:] Украјинистика и словенски свет, зборник научних радова : поводом 25 година украјинистике на Универзитету у Београду, главни уредник Људмила Поповић, Београд 2017, с. 159-166.

Космеда T., Ego i Alter Ego Tapaca Шевченка в комунікативному просторі щзоденникового дискурсу, Дрогобич 2012.

Космеда Т., Лингвокалейдоскоп: живые речевые процессы (на материале русского и украинского языков), Саарбрюккен 2017.

Лингвистический энщиклопедический словарь, гл. ред. В. Н. Ярцева, Москва 1990.

Намачинська Г. Я., Підгрунтя лексикографічної конщепиї В. Даля : етнокультурний acneкm, [в:] „Наукові праці Чорноморського державного університету імені Петра Могили комплексу «Києво-Могилянська академія». Серія «Філологія. Мовознавство»", гол. ред. проф. Л. П. Клименко, Миколаїв 2016, вип. 266, т. 278, с. 88-91.

Ожегов С. И., Словарь русского языка, под ред. Н. Ю. Шведовой, 22-е изд., стер., Москва 1990.

Селігей П., Мовна свідомість : структура, типологія, виховання, Київ 2012.

Словарь современного русского литературного языка, в 17 томах, под ред.

В. И. Чернышёва, Москва-Ленинград 1950-1965.

Словник української мови, в 11 томах, за ред. І. К. Білодіда, Київ 1970-1980.

\section{Spysok vykorystanoi literatury [References]}

Dal V. I., Tolkovyj slovar zhivogo velikorusskogo jazyka [Explanatory Dictionary of Live Great Russian Language], v 4 tomah, Moskva 1981.

Kosmeda T., Zaborona ukrainskoi movy $i$ unikalnist yii zapozychuvalnoho potentsialu [The Ukrainian Language Prohibition and the Unique Features of its Borrowing Potential], [v:] Ukrajynystyka y slovensky svet, zbornyk nauchnykh radova : povodom 25 hodyna ukrajynystyke na Unyverzytetu u Bielhradi, hlavny urednyk L. Popovych, Bielhrad 2017, s. 159-166.

Kosmeda T., Ego $i$ Alter Ego Tarasa Shevchenka $v$ komunikatyvnomu prostori shchodennykovoho dyskursu [Ego and Alter Ego of Taras Shevchenko in Communicative Space of Diary Discourse], Drohobych 2012.

Kosmeda T., Lingvokalejdoskop : zhivye rechevye processy (na materiale russkogo i ukrainskogo yazykov) [Linguo-Kaleidoscope: Processes of Live Speech (on the Material of Russian and English)], Saarbrjukken 2017.

Lingvisticheskij e'ntsiklopedicheskij slovar' [Linguistic Encyclopedic Dictionary], gl. red. V. N. Yarceva, Moskva 1990.

Namachynska H. Ya., Pidgruntia leksykohrafichnoi kontseptsii V. Dalia : etnokulturnyi aspekt [Fundamentals of Lexicographic Conception of V. Dahl: Ethno-Cultural Aspect], 
[v:] „Naukovi pratsi” Chornomorskoho derzhavnoho universytetu imeni Petra Mohyly kompleksu "Kyievo-Mohylianska akademiia", seriia "Filolohiia. Movoznavstvo", hol. red. prof. L. P. Klymenko, Mykolaiv 2016, vyp. 266, t. 278, s. 88-91.

Ozhegov S. I., Slovar russkogo jazyka [Dictionary of the Russian Language], pod red. N. Ju. Shvedovoj, 22-e izd., ster., Moskva 1990.

Selihei P., Movna svidomist : struktura, typolohiia, vykhovannia [Language Consciousness : Structure, Typology, Education], Kyiv 2012.

Slovar sovremennogo russkogo literaturnogo jazyka [Dictionary of Modern Literary Russian Language], v 17 tomah, pod red. V. I. Chernyshjova, Moskva Leningrad 1950-1965.

Slovnyk ukrainskoi movy [The Ukrainian Language Dictionary], v 11 tomakh, za red. I. K. Bilodida, Kyiv 1970-1980. 